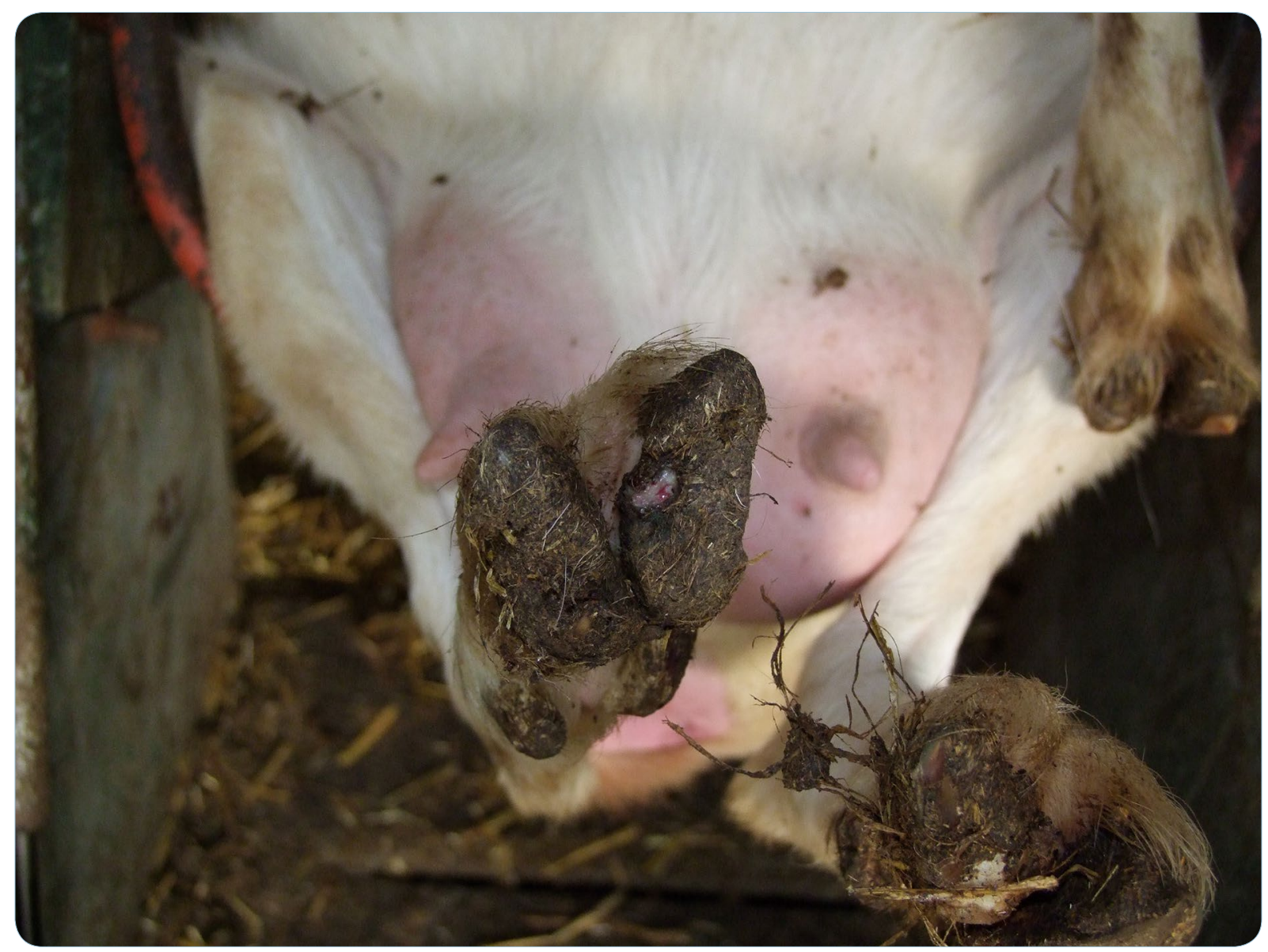

A case report of lameness in two dairy goat herds; a suspected combination of nutritional factors concurrent with treponeme infection

Groenevelt et al. 


\title{
A case report of lameness in two dairy goat herds; a suspected combination of nutritional factors concurrent with treponeme infection
}

\author{
Margit Groenevelt ${ }^{1 *}$, Katharine Anzuino ${ }^{2}$, Sue Smith ${ }^{3}$, Michael R. F. Lee ${ }^{1,4}$ and Rosemary Grogono-Thomas ${ }^{1}$
}

\begin{abstract}
Background: Two dairy goat farms with high level of lameness in lactating animals were presented for further investigation. Farm 1 and Farm 2 presented with 37 and $67 \%$ morbidity, respectively. Both farms had an all year round indoor system, feeding ad libitum concentrate with forage available at all times.

Case presentation: The lameness was found to be based in the foot. Previous treatments consisting of biweekly footbathing with zinc sulphate, spraying lesions with oxytetracycline spray and packing lesions with copper crystals on a single occasion and single injections with long acting oxytetracycline had not been successful. Mild cases had signs of haemorrhaging in the white line or on the sole of the foot. Moderate cases showed under running of the wall horn or small areas of exposed sole corium. Severe cases would consist of horn or wall separation with the corium exposed and infected. In extreme cases only the wall horn of the claw remained, with a large area of necrotic tissue in the centre and no healthy corium visible. Only one animal was seen to have interdigital lesions. Polymerase chain reaction (PCR) and culture of swabs taken from exposed corium and the interdigital space were negative for Dichelobacter nodosus but PCR for treponemes were positive in both the adults and the youngstock tested. Due to the high level of concentrate in the diet of these goats, nutrition was thought to contribute to the problem. Transcutaneous rumen fluid samples were taken and pH was measured on both farms, with $35 \%$ of the samples below pH value 5.5 .
\end{abstract}

Conclusion: No definite diagnosis could be made. However, the results suggest both treponemes and nutrition play a role in the aetiology of the lameness. The initial sole or wall horn lesions were thought to be secondarily infected by treponemes. Further investigation is needed to definitively diagnose the cause and contributing factors for this lameness.

Keywords: Dairy goats, Lameness, Treponemes, Nutrition

\section{Background}

Lameness in sheep and dairy cattle has been extensively researched. It is clearly demonstrated that lameness in dairy cows is a painful condition [1] and has an influence on fertility [2], productivity [3] and longevity [4]. In sheep, lameness has been associated with weight loss [5], decreased fertility and lamb growth rates [6]. It

\footnotetext{
*Correspondence: margit.groenevelt@bristol.ac.uk

${ }^{1}$ School of Veterinary Science, University of Bristol, Langford,

Somerset BS40 5DU, UK

Full list of author information is available at the end of the article
}

is estimated that the average lameness level in the dairy cattle herd in the UK is $36 \%$ [7] and for sheep this lies between 8 and $10 \%[8,9]$. In contrast, very little research has been undertaken into lameness in dairy goats. Previous observations on dairy goat farms in the UK estimated the prevalence of lameness to be between 9.1 [10] and $19.2 \%$ [11]. In sheep, $90 \%$ of lameness cases are caused by footrot (Dichelobacter nodosus) [9]. D. nodosus has also been confirmed as a cause of lameness in goats $[12,13]$. However, Hill et al. [10] found only one of four dairy goat farms investigated to be affected by footrot, 
with $14.2 \%$ of animals showing lesions. There is little published evidence for high levels of footrot in UK dairy goat herds. However, in the authors' experience, farmers often presume a high prevalence of lameness in their goats must be due to footrot infection. It is reported that up to $100 \%$ of dairy goat farms may have some goats with overgrown feet and up to $91.7 \%$ of farms have goats with severely overgrown feet $(>2.5 \mathrm{~cm})$ [11]. Severely overgrown or deformed feet are associated with higher mobility scores and claw temperatures in dairy goats and could therefore contribute to lameness levels on farm [14]. Other lesions found on UK dairy goat farms include horn separation, white line lesions, abscesses of the sole, foreign bodies, and granulomatous lesions [10]. In other countries, major lameness causes in goats include footrot [15], white line lesions, foreign bodies [16] and, in addition, foot abscesses and sole ulcerations [17].

In dairy cattle a link between ruminal acidosis due to a high non-structural-carbohydrate (concentrate) diet and claw horn lesions is often suggested. Although in cattle this relationship is well documented, there is still no conclusive evidence as to the causative pathogenesis [18]. In goats, there is no literature available that establishes a link between nutrition and lameness. There is some work published on different feeding regimes for intensive dairy herds $[16,19,20]$ but none of these studies have been carried out for longer than 8 months during lactation or on large groups of animals. The impact of these intensive, high concentrate feeding regimes on animal health, including lameness, is currently unknown.

In recent years, new foot diseases associated with treponeme infection have been described. Treponemes have been suggested as the causative agent in contagious ovine digital dermatitis (CODD), causing severe lameness in sheep. Multiple strains/serotypes of treponemes have been identified in association with CODD [21]. These strains have some genetic similarity with those associated with bovine digital dermatitis (BDD), despite different clinical lesions and pathology [22]. More recently, nonhealing white line lesions (NhWL) and sole ulcers (NhSU) in cattle have been reported to be associated with treponemes [22]. To date there has been one publication that reports the isolation of treponemes from goats' feet from lesions that look similar to CODD [23]. This paper reports on lameness observations in two large dairy goat herds in the UK, possibly associated with nutrition and treponemes isolated from the lesions.

\section{Case presentation}

\section{Farm visits}

The investigation took place on two dairy goat farms in the South West of England. Both had been dealing with high levels of lameness for over four years. Intervention measures had focussed on treatment and prevention of footrot and had not resulted in a reduction of lameness. Their attending veterinary surgeons had referred these cases for further investigation. Each farm was visited at least three times throughout the investigation. A full history was taken from the farmers and a thorough inspection was carried out of the housing, milking parlour, bedding and feeding regime (see Table 1).

\section{Lameness scoring}

Lameness assessment and scoring was carried out according to Anzuino et al. [11] as in Table 2 on all lactating animals during morning milking on both farms. Lameness was define as a score $\geq 1$. The goats were scored after exiting the parlour on a flat, concrete passage way. Care was taken that the scorer did not obstruct the goats so normal behaviour could be seen. Youngstock (between 2 and 12 months of age) were not scored but were observed for lameness in their pens.

The lameness prevalences in the lactating animals were 37.1 \% for Farm 1 and 69.6 \% for Farm 2 (Fig. 1). No lameness was detected in the youngstock. Youngstock was kept in different housing to the adults on both

Table 1 Overview of farm details

\begin{tabular}{lll}
\hline & Farm 1 & Farm 2 \\
\hline Number of lactating does & 313 & 540 \\
Breed & British Saanen, British Toggenburg & British Saanen, British Toggenburg, British Alpine \\
Housing & Straw bedding & Straw bedding \\
Feeding & Ad libitum concentrates Ad libitum grass hay or haylage & Ad libitum concentrates Ad libitum grass silage \\
Foot trimming & Every 6-8 weeks & Every 3 months \\
Foot bathing & Not carried out & Every 2-3 weeks (zinc sulphate) \\
Production level & 1000 l/doe/year & 1050 l/doe/year \\
Kidding regime & 1 kidding/doe/year & 1 kidding/doe/year \\
Parlour & Flat entry and exit & Sloped entry and exit \\
\hline
\end{tabular}


Table 2 Lameness score definitions [11]

\begin{tabular}{ll}
\hline Score & Definition \\
\hline 0 & Goat places full weight on all four limbs, moves forward freely with an even gait \\
1 & Goat has a definite limp on one or more legs, but bearing weight and moves forward freely \\
2 & Goat has some difficulty moving forward, severe limp, bearing little weight on one or more legs, may be a degree of goose-stepping \\
3 & Goat has some difficulty moving forward, non-weight bearing on one or more legs, or may'goose-step' high or walk on the knees \\
\hline
\end{tabular}

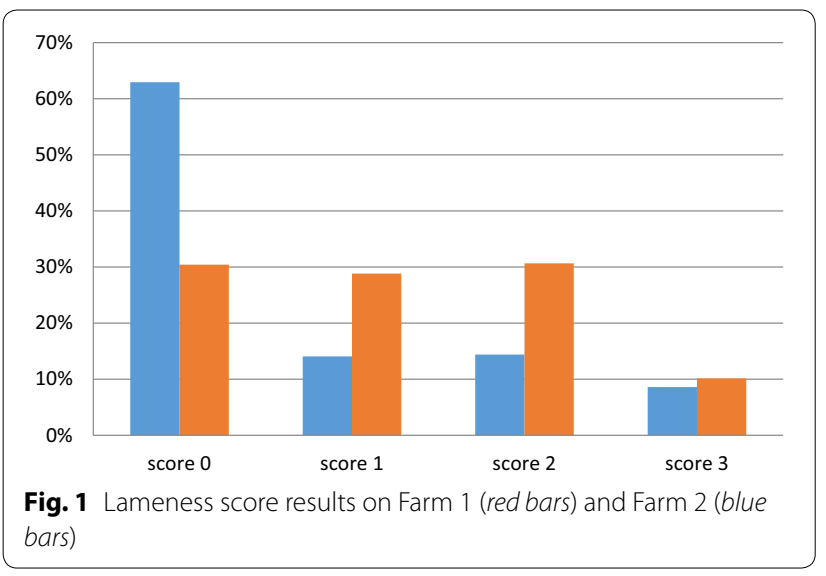

farms although in close proximity. No biosecurity measures were in place between youngstock and the lactating herds.

\section{Clinical examination}

The goats were clinically examined on two occasions on each farm, firstly during treatment sessions and later during routine foot trimming session. During each session, 15-20 goats were closely examined by the researchers. These animals were selected based on lameness score, lesion type or absence of lameness to ensure a full overview of the condition of the feet was acquired. All four feet of each animal were examined, regardless of which leg the animal had been lame on. Care was taken not to interfere with the normal trimming and treatment routines on either farm in order to assess the normal protocols.

During these sessions a variety of foot lesions were observed. The different lesions were classed as mild to extreme (Table 3; Figs. 2, 3, 4, 5). Lesions were most often seen in one leg and one claw but could affect both claws on the same leg or multiple legs. Only on one occasion were lesions in the interdigital space observed that resembled scald, the skin being moist, red and with a foul smell.

In the mild and moderate cases no distinct smell was detected. There was no underrunning of horn detected until the more advanced stages. In the earlier stages the horn seemed to have been lysed instead of underrun.

In the majority of cases the feet were trimmed and the lesions sprayed once with oxytetracycline spray ('Engemycine Spray', MSD Animal Health, Milton Keynes, UK) on both farms. Occasionally the lesions would be covered with a $0.5 \mathrm{~cm}$ thick layer of copper sulphate crystals $(25 \%$ $\mathrm{Cu}$ content, various suppliers) and the foot bandaged for 2 or 3 days. Injectable antibiotics were not used during our visits but had been used previously and were reported to have low success rates ('Oxytetrin LA', $200 \mathrm{mg} / \mathrm{ml}, 1 \mathrm{ml} / \mathrm{kg}$ intramuscular, MSD Animal Health, Milton Keynes, UK). Herd treatments using zinc sulphate foot baths once every 2 weeks ('Golden Hoof' at 10 \% concentration, Shep Fair Animal Health, Abergavenny, UK) were reported to help keep the problem under control although did not prevent new cases. Neither farm kept records of the treatments administered to individual animals so it was not possible to see the progression of cases. Farm staff on both farms, however, felt that the recovery rates for all lesions and treatments were extremely low at less than $20 \%$.

\section{Differential diagnosis}

As the lesions that were seen on the farm did not resemble footrot, the diagnosis after clinical examination remained unclear. Footrot, treponeme infection, laminitis and primary claw horn lesions with secondary infections were

Table 3 Description of classification of lesion severity

\begin{tabular}{ll}
\hline Severity & Description \\
\hline Mild & Haemorrhage in the white line or the sole area of the foot (Fig. 2) \\
Moderate & Under running of the horn of wall or sole, sometimes with small areas of corium exposed (Fig. 3) \\
Severe & Large areas of wall or sole exposed with the underlying corium being infected (Fig. 4) \\
Extreme & Only the wall horn of the foot remained, leaving a large area of necrotic tissue with no healthy corium visible (Fig. 5) \\
\hline
\end{tabular}




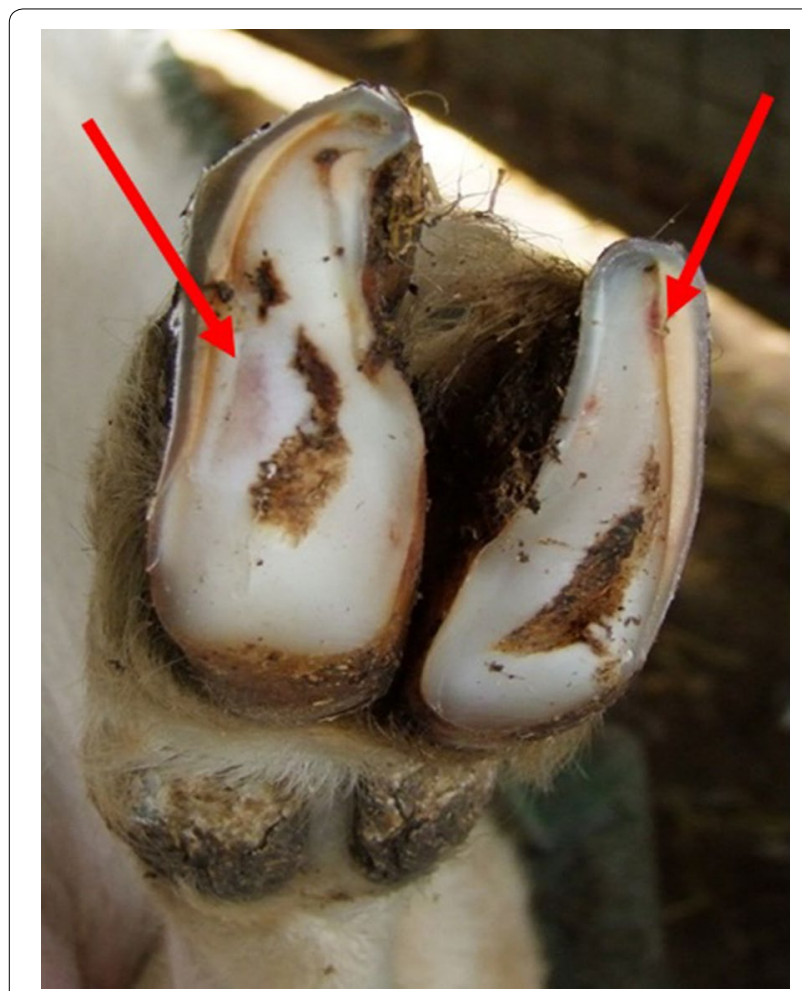

Fig. 2 Mild lesion showing haemorrhage in the white line or the sole area of the foot (see arrows)

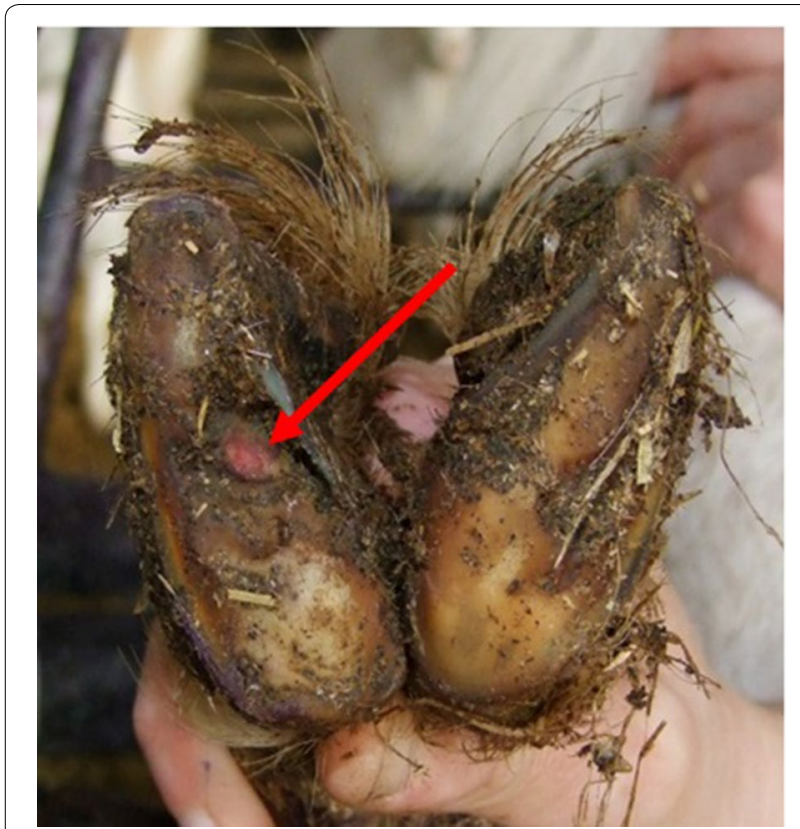

Fig. 3 Moderate lesion showing a small area of corium exposed in the sole horn (see arrow)

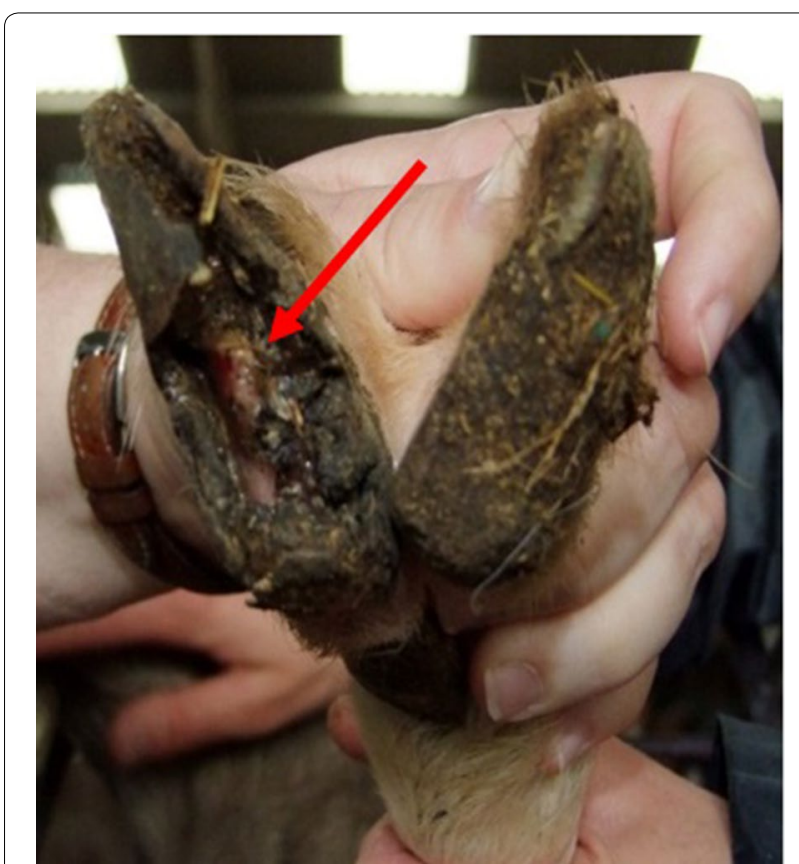

Fig. 4 Severe lesion showing a large area of sole exposed with the underlying corium being infected (see arrow)

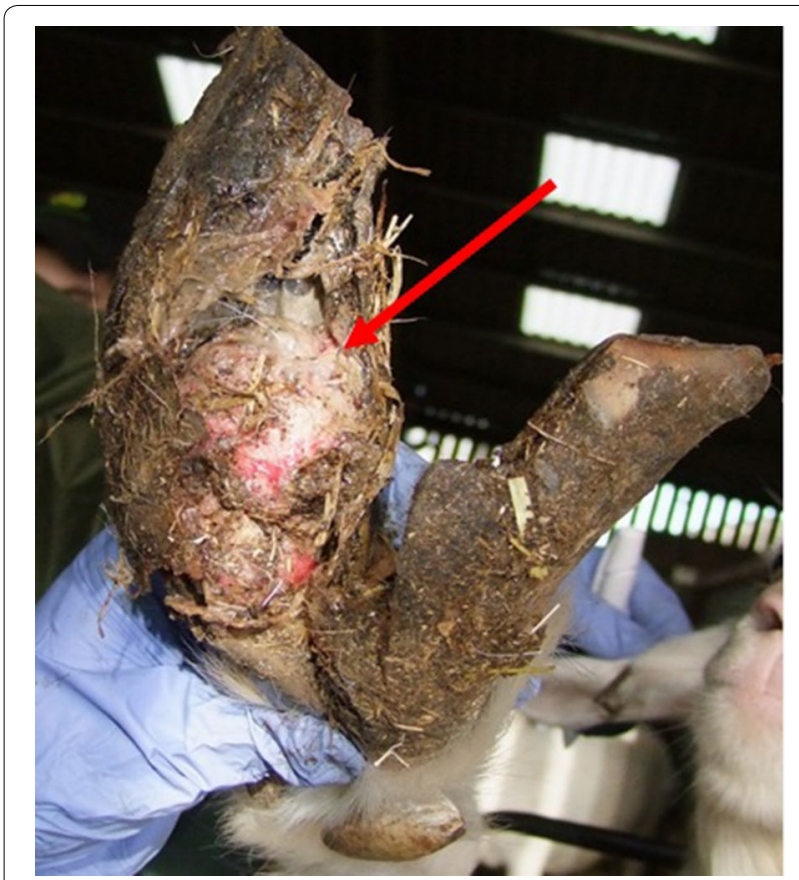

Fig. 5 Extreme lesion showing only the wall horn of the foot remaining, leaving a large area of necrotic tissue with no healthy corium visible (see arrow) 
still considered as possible diagnoses. Additional diagnostics were carried out in order to differentiate further.

\section{Further diagnostics}

\section{Swabs for processing by PCR}

During the clinical examination dry swabs were taken from the affected area (interdigital space, exposed corium or laminae) of 20 lame, lactating animals on Farm 1, 16 lame, lactating animals on Farm 2 and two non-lame youngstock on Farm 2. These were taken after the farm staff had finished trimming the feet and before treatments were administered. The swabs were placed in Eppendorf tubes containing $0.5 \mathrm{ml}$ of sterile TRIS EDTA Buffer ( $\mathrm{pH}$ 8.0) during transport and processed by polymerase chain reaction (PCR) at the laboratory facilities of the University of Bristol. PCR primers used are shown in Table 4.

All swabs were found to be negative on PCR for $D$. nodosus. All of the swabs tested positive however on PCR for treponemes. On Farm 2, two samples were taken from non-lame youngstock which also tested negative for D. nodosus and positive for treponemes.

\section{Nutritional breakdown}

Both farms used the same concentrate feed which formed approximately $70 \%$ of the goats' diet (BOCM Pauls Ltd., Ipswich, UK). Nutrient content, as supplied by the manufacturer is shown in Table 5.

This concentrate was being fed truly ad libitum with either grass hay, haylage or silage offered ad libitum. Although the goats were housed on barley straw this was not intended to constitute a significant amount of the diet. On both farms the quality and type of the forage offered varied greatly between visits. The feeding regime did not differ depending on stage of lactation, production level or dry period. Prior to weaning, the kids would be offered the same concentrates ad libitum. Post weaning, they were fed the same diet as the adult goats.

\section{Rumen pH}

As the nutrition was thought to play a role in the development of the lesions seen, transcutaneous rumen samples were taken from a selection of mid lactation goats, regardless of whether or not they were lame. The samples were taken from the ventral rumen, using a technique
Table 5 Diet as formulated to contain

\begin{tabular}{lr}
\hline DM38 (\%) & $\mathbf{8 7 . 8}$ \\
\hline Protein (\% as fed) & 18.2 \\
Starch (\% as fed) & 10.7 \\
Sugar (\% as fed) & 7.9 \\
Oil (\% as fed) & 4.9 \\
NCGD $^{\text {a }} \%$ DM) & 75.7 \\
NDF $^{b}$ (\% DM) & 39.3
\end{tabular}

a Neutral cellulase gamminase digestibility

${ }^{\mathrm{b}}$ Non detergent fibre

described for cattle [24]. The location used was on a line with the dorsal edge of the patella and approximately $10 \mathrm{~cm}$ caudal to the last rib. A minimum of $1 \mathrm{ml}$ was obtained from each animal and analysed for $\mathrm{pH}$ on farm using the Checker Portable pH Meter (Hanna Instruments, Woonsocket, USA). A total of 18 rumen samples were taken on Farm 1 and 22 from Farm 2 (Table 6). Of the samples taken $17.5 \%$ were below value 5.5 , which is considered to be acidotic $[25,26]$.

\section{Diagnosis and discussion Microbial factors}

On clinical examination, it became apparent that the cause of lameness in these goats was located in the foot. In sheep flocks where the majority of foot lameness is caused by footrot, $D$. nodosus is found on the feet of both healthy and lame sheep [21]. In the cases described above, there was no evidence of $D$. nodosus.

All samples tested however, were positive for treponemes, suggesting a potential role for these bacteria in the aetiology of lameness on the two study farms. CODD was first described in sheep in 1997 [27] with spirochaetes cultured from lesions of affected animals [28]. These spirochaetes were subsequently speciated as treponemes and found to be the same as the treponemes involved in the aetiology of BDD [29]. The presence of the treponemes on swabs from the youngstock indicate that the youngstock carry the same bacteria. Neither farm practiced a high level of biosecurity between youngstock and adults. Although the groups were not in physical contact, farm staff would readily walk between groups and the same equipment was used. It is interesting to

Table 4 PCR primers used

\begin{tabular}{llrc}
\hline Primer specificity & Primer (sequence) & Predicted size (bp) & Reference \\
\hline D. Nodosus & CTCGGTACCGAGTATTTCTACCCAACACCTAC 50 CGGGGTTATGTAGCTTGC & 783 & [35] \\
Spirochaete specific 16S & RNAF AGAGTTTGATCMTGGCTCAGRNAR ACGGCTACCTTGTTACGACTTCAC & 1500 & {$[36]$} \\
Treponeme specific 16S & TPF AARCATGCAAGTCGARCGGCAAGTPR1 TCCATTGCGGAATATTCTTA & 335 & {$[37]$} \\
\hline
\end{tabular}


Table 6 Rumen pH results

\begin{tabular}{llc}
\hline PH & Farm $\mathbf{1}[\mathbf{n}=\mathbf{1 8}(\%)]$ & Farm $\mathbf{2}[\mathbf{n}=\mathbf{2 2}(\%)]$ \\
\hline$<5.5$ & $3(16.7)$ & $4(18.2)$ \\
$>5.5$ to $<5.8$ & $6(33.3)$ & $3(13.6)$ \\
$>5.8$ & $9(50)$ & $15(68.2)$ \\
\hline
\end{tabular}

note, however, that no lameness was observed in the youngstock.

In cattle lameness, recent findings suggest that treponemes are involved in 'NhWL' [22]. These lesions are typically progressive, painful lesions that involve infection of the corium. Treatment is often unsuccessful [30]. It is hypothesised that in the cases described here the treponemes are in fact a secondary invader of exposed or compromised corium or laminae. This would provide an explanation as to why the lesions are not seen in the youngstock. The youngstock are not exposed to the same risk factors as the lactating does and therefore do not develop the claw horn lesions that seem to precede the infected lesions. Moore et al. [21] also report the presence of treponemes on $38 \%$ of healthy sheep feet, suggesting other factors than only the presence of the bacteria play a role in developing disease.

\section{Physiological and nutritional factors}

As housing and feeding regime were similar between the youngstock and adults, the main difference between the groups was that the adults were lactating. As both calving and metabolic stress can have a negative impact on hoof health in cattle $[18,31]$, this was considered to be of significance in these goat herds. To date, no work has been done to investigate whether or not kidding has the same effect on the suspensory apparatus of the goats' foot as it does on cows' feet. It seems likely, however, that the hormonal changes that might be involved with the weakening of the suspensory apparatus in cattle would have the same effect within a goat [31]. When kept within their usual housing environment the goats normally have soft underfoot conditions. They should therefore not experience the same trauma described in dairy cattle that results from prolonged periods standing on concrete [32]. However, in situations where the quality of the hoof horn is reduced, the foot may be more sensitive to trauma. It is known that the feeding of high levels of non-structural-carbohydrates which are rapidly degraded in the rumen, such as starch, increases the incidence of lameness in dairy herds [18, 33]. Presently, the direct link between acidosis and claw horn lesions is unclear but associations have been made with the production of lesser quality horn [18]. Both herds were fed on the same ad libitum concentrate diet and levels of ruminal acidosis were investigated in the lactating herds. The high concentrate ration fed to both herds was suspected to induce either chronic or sub acute ruminal acidosis (SARA). It must be noted that the diets were formulated to contain high density short fibre from byproducts in replacement of forage non detergent fibre (NDF). However, the varying type and quality of forage offered was thought to influence intake and therefore rumen $\mathrm{pH}$ might fluctuate considerably. Rumen $\mathrm{pH}$ of youngstock was not determined and so greater buffering or diet selection in this group could not be ruled out, potentially limiting acidosis in this group. Although the role of nutrition in the aetiology of cattle claw horn lesions still leaves many questions [18] it is thought that in the current case nutritional factors could not be ruled out. Indeed, when analysing the rumen $\mathrm{pH}$ samples, $40 \%$ of samples taken were found to be below 5.8 with $17.5 \%$ below 5.5 , a level which in cattle is believed to be indicative of ruminal acidosis [34]. The optimal ruminal $\mathrm{pH}$ for goats is reported to be over six, indicating a level of ruminal acidosis in the lactating does [25, 26]. In goats, little is known about the functionality of the rumen under different values of $\mathrm{pH}$ in contrast to the extensive literature on cattle. Bava et al. [20] report the ability of goats to adapt to relatively low rumen $\mathrm{pH}$ and show little adverse effect of feeding non-forage based diets during lactation. These studies were short and concentrated on a narrow period of time during peak lactation. No evidence is available on the effect of this feeding regime over an extended period of time, which would include the dry period and transition.

\section{External risk factors}

Risk factors for the development of sole haemorrhaging and white line lesions in dairy cattle include incorrect weight distribution, changes to the pedal bone around calving [31], prolonged periods of standing on concrete and the use of grooved concrete in alleys and tracks [32]. As dairy goats are housed differently to dairy cattle (i.e. on bedding rather than concrete) it may not be surprising that under normal circumstances, hoof horn lesions such as sole ulcers are not reported as a cause of lameness in the UK dairy goat herd. Although white line lesions are common [10], in many cases they are not thought to cause lameness. The goats from Farm 1 always walked on flat surfaces and the time stood or walking on concrete was limited. The animals from Farm 2 however, had to walk up and down a relatively narrow and steep ramp to enter and exit the milking parlour and it is possible this causes bruises and white line lesions within this herd and may contribute to the higher incidence of lameness on Farm 2. The goats on Farm 1 only had to travel over level ground but they had to perform a $180^{\circ}$ turn with 
rough concrete underfoot. In dairy cattle rough concrete is demonstrated as a risk factor for white line lesions [32].

\section{Conclusion}

A definite diagnosis cannot be made at this stage. It is, however, hypothesised that the aetiology of these lameness cases may be twofold with both nutritional and infectious involvement. A claw horn lesion develops first, either white line lesion or sole ulcer, due to lower quality horn produced as a result of a poor diet and the specific external risk factors listed for each farm. This claw horn lesion subsequently becomes infected with treponemes, resulting in a painful, progressive lesion that is difficult to cure. Further investigations, including post mortem results, histology and further identification of the treponemes involved, are needed in order to reach a diagnosis. Further work is also required on the impact of extended high concentrate feeding on goat health and specifically lameness.

\section{Abbreviations}

BDD: bovine digital dermatitis 279; CODD: contagious ovine digital dermatitis 280; NhWL: non healing white line lesion 281; NhSU: non healing sole ulcer 282; NCGD: neutral cellulase gamminase digestibility 283; NDF: non detergent fibre 284; PCR: polymerase chain reaction 285; SARA: sub acute ruminal acidosis 286; UK: United Kingdom.

\section{Authors' contributions}

MG participated in the investigations carried out at both farms, sample taking and drafted the manuscript. KA participated in all the sample taking, progression of the investigation and assisted in drafting the manuscript. SS participated in the sample taking and progression of the investigation. ML assisted in interpretation of results and nutritional constitution and assisted in drafting the manuscript. RGT participated in design and progression of the investigation and assisted in drafting the manuscript. All authors read and approved the final manuscript.

\section{Author details}

1 School of Veterinary Science, University of Bristol, Langford, Somerset BS40 5DU, UK. ${ }^{2}$ Willow Walk, Honiton EX14 2FX, UK. ${ }^{3}$ Castle Cary BA7 7EG, UK.

${ }^{4}$ Rothamsted Research, North Wyke, Okehampton, Devon EX20 2SB, UK.

\section{Acknowledgements}

This work was supported by Combating Endemic Diseases of Farmed Animals for Sustainability (CEDFAS) initiative, Grant No. BBE01870X1 from the Biotechnology and Biological Sciences Research Council (BBSRC). The authors would also like to thank Nick Perkins, Kat Bazeley, Delaware Veterinary Group and Langford Veterinary Services for the opportunity to investigate on these farms. We would also like to thank Claire Phythian, Jesse Bonwitt, James Ryder, Bleddyn Hobbs and Hannah Slyfield for their assistance in sample taking and on farm investigations.

\section{Competing interests}

The authors declare that they have no competing interests.

Received: 4 February 2015 Accepted: 23 November 2015

Published online: 16 December 2015

\section{References}

1. Whay HR, Waterman AE, Webster AJF. Associations between locomotion, claw lesions and nociceptive threshold in dairy heifers during the peripartum period. Vet J. 1997;154(2):155-61.
2. Huxley JN, Main DCJ, Bell NJ, Whay HR. Lameness and infertility in UK dairy herds. Two intractable problems. Reprod Domest Anim. 2007:42(1):12

3. Reader JD, Green MJ, Kaler J, Mason SA, Green LE. Effect of mobility score on milk yield and activity in dairy cattle. J Dairy Sci. 2011;94(10):5045-52.

4. Booth CJ, Warnick LD, Grohn YT, Maizon DO, Guard CL, Janssen D. Effect of lameness on culling in dairy cows. J Dairy Sci. 2004;87(12):4115-22.

5. Nieuwhof GJ, Bishop SC, Hill WG, Raadsma HW. The effect of footrot on weight gain in sheep. Animal. 2008;2(10):1427-36.

6. Wassink GJ, King EM, Grogono-Thomas R, Brown JC, Moore LJ, Green LE. A within farm clinical trial to compare two treatments (parenteral antibacterials and hoof trimming) for sheep lame with footrot. Prev Vet Med. 2010;96(1/2):93-103.

7. Barker ZE, Leach KA, Whay HR, Bell NJ, Main DCJ. Assessment of lameness prevalence and associated risk factors in dairy herds in England and Wales. J Dairy Sci. 2010;93(3):932-41.

8. Grogono-Thomas R, Johnston AM. A study of ovine lameness. MAFF Final Report. London; 1997 Contract No: MAFF open contract OC59 $45 \mathrm{~K}$.

9. Kaler J, Green LE. Naming and recognition of six foot lesions of sheep using written and pictorial information: a study of 809 English sheep farmers. Prev Vet Med. 2008;83(1):52-64.

10. Hill NP, Murphy PE, Nelson AJ, Mouttotou LE, Green LE, Morgan $\mathrm{KL}$. Lameness and foot lesions in adult British dairy goats. Vet Rec. 1997;141(16):412-6.

11. Anzuino K, Bell NJ, Bazeley KJ, Nicol CJ. Assessment of welfare on 24 commercial UK dairy goat farms based on direct observations. Vet Rec. 2010;167(20):774-80.

12. Depiazzi $\sqcup$, Richards RB, Henderson J, Rood JI, Palmer M, Penhale WJ. Characterisation of virulent and benign strains of Bacteroides nodosus. Vet Microbiol. 1991;26(1/2):151-60.

13. Bennett G, van Loenen A, Zhou H, Sedcole R, Hickford J. The detection of Dichelobacter nodosus and Fusobacterium necrophorum from footrot lesions in New Zealand goats. Anaerobe. 2009;15(4):177.

14. Ajuda IG, Vieira AC, Almeida de FF, Stilwell G, editors. Lameness on dairy goats: What is the level of pain experienced and how we evaluate it? Preliminary results. International Conference on Lameness in Ruminants; 2013 11-14 August; Bristol, United Kingdom.

15. Christodoulopoulos G. Foot lameness in dairy goats. Res Vet Sci. 2009;86(2):281-4

16. Mgasa MN, Arnbjerg J. Occurrence of lameness and digital lesions in Tanzanian goats. Small Ruminant Res. 1993;10(1):55-62.

17. De Aguiar GMN, Assis ACO, Silva TRD, Araujo JRB, Garino JF, Simoes SV et al. Infectious foot problems in sheep and goats in the semiarid region of Paraiba [Portuguese]. Cienc Anim Bras. 2009;10(Supplement 1):585-90.

18. Lean IJ, Westwood CT, Golder HM, Vermunt JJ. Impact of nutrition on lameness and claw health in cattle. (Special Issue: Lameness and claw lesions in sows, cows and small ruminants.). Livest Sci. 2013;156(1/3):71-87.

19. Rapetti L, Bava L, Tamburini A, Crovetto GM. Feeding behaviour, digestibility, energy balance and productive performance of lactating goats fed forage-based and forage-free diets. Ital J Anim Sci. 2005;4(1):71-83.

20. Bava L, Rapetti L, Crovetto GM, Tamburini A, Sandrucci A, Galassi G, et al. Effects of a nonforage diet on milk production, energy, and nitrogen metabolism in dairy goats throughout lactation. J Dairy Sci. 2001;84(11):2450-9.

21. Moore LJ, Woodward MJ, Grogono-Thomas R. The occurrence of treponemes in contagious ovine digital dermatitis and the characterization of associated Dichelobacter nodosus. Vet Microbiol. 2005;111(3/4):199-209.

22. Evans NJ, Blowey RW, Timofte D, Isherwood DR, Brown JM, Murray R, et al. Association between bovine digital dermatitis treponemes and a range of'non-healing' bovine hoof disorders. Vet Rec. 2011;168(8):214.

23. Clegg S, Sullivan L, Bell J, Blowey R, Newbrook K, Duncan J, et al. editors. The expanding host range of digital dermatitis treponemes. Cattle lameness conference. Worcester; 2014

24. Nordlund KV, Garrett EF, Oetzel GR. Herd-based rumenocentesis: a clinical approach to the diagnosis of subacute rumen acidosis. Food Anim Med Manag. 1995;17(8):s48-56.

25. Gupta SR, Yadav R, Sharma CS, Gattani A. Dietary induced metabolic acidosis in goats and its successful therapeutic management. Vet Pract. 2012;13(2):312-4 
26. Moore JA, Poore MH, Luginbuhl JM. By-product feeds for meat goats: effects on digestibility, ruminal environment, and carcass characteristics. J Anim Sci. 2002;80(7):1752-8.

27. Harwood DG, Cattell JH, Lewis CJ, Naylor R. Virulent foot rot in sheep. Vet Rec. 1997;140(26):687.

28. Naylor RD, Martin PK, Jones JR, Burnell MC. Isolation of spirochaetes from an incident of severe virulent ovine footrot. Vet Rec. 1998;143(25):690-1.

29. Sayers G, Marques PX, Evans NJ, O'Grady L, Doherty ML, Carter SD, et al. Identification of spirochetes associated with contagious ovine digital dermatitis. J Clin Microbiol. 2009;47(4):1199-201.

30. Holzhauer M, Pijl R, editors. Non-healing white line lesion, advanced experience. 16th International symposium and 8th conference on lameness in ruminants; 2011. Rotorua, New Zealand.

31. Tarlton JF, Holah DE, Evans KM, Jones S, Pearson GR, Webster AJF. Biomechanical and histopathological changes in the support structures of bovine hooves around the time of first calving. Vet $J$. 2002;163(2):196-204.

32. Barker ZE, Amory JR, Wright JL, Mason SA, Blowey RW, Green LE. Risk factors for increased rates of sole ulcers, white line disease, and digital dermatitis in dairy cattle from twenty-seven farms in England and Wales. J Dairy Sci. 2009;92(5):1971-8.
33. Manson FJ, Leaver JD. The influence of concentrate amount on locomotion and clinical lameness in dairy cattle. Anim Prod. 1988;47(2):185-90.

34. Dawson KA, Alison MJ. Digestive disorders and nutritional toxicity. In: Hobson PN, editor. The rumen microbial ecosystem. London: Elsevier; 1988. p. 633-60.

35. La Fontaine S, Egerton JR, Rood JI. Detection of Dichelobacter nodosus using species-specific oligonucleotides as PCR primers. Vet Microbiol. 1993;35(1/2):101-17.

36. Collighan RJ, Woodward MJ. Spirochaetes and other bacterial species associated with bovine digital dermatitis. FEMS Microbiol Lett. 1997;156(1):37-41.

37. Moore LJ, Wassink GJ, Green LE, Grogono-Thomas R. The detection and characterisation of Dichelobacter nodosus from cases of ovine footrot in England and Wales. Vet Microbiol. 2005;108(1/2):57-67.

\section{Submit your next manuscript to BioMed Central and we will help you at every step:}

- We accept pre-submission inquiries

- Our selector tool helps you to find the most relevant journal

- We provide round the clock customer support

- Convenient online submission

- Thorough peer review

- Inclusion in PubMed and all major indexing services

- Maximum visibility for your research

Submit your manuscript at www.biomedcentral.com/submit
() Biomed Central 